\title{
Concept «Religion» in the Consciousness of Young People: Psycholinguistic Analysis
}

\section{Концепт «РЕЛІГІЯ» у свідомості молоді: психолінгвістичний аналіз}

\author{
Natalia Kostruba \\ Ph.D. in Psychology, \\ Lecturer
}

\author{
Наталія Коструба \\ кандидат психологічних наук, \\ старший викладач
}

\author{
E-mail: chmil.nata@ukr.net \\ https://orcid.org/0000-0002-3852-4729 \\ ResearcherID: Y-6251-2019
}

Lesya Ukrainka Eastern European

National University

13, Volya Avenue, Lutsk,

Volyn reg., Ukraine, 43025
Східноєвропейський національний університет імені Лесі Українки

$\bowtie$ пр. Волі, 13, Луцьк,

Волинська обл., Україна, 43025

Original manuscript received August 15, 2019

Revised manuscript accepted March 16, 2020

\begin{abstract}
Objective. The creation of the Orthodox Church of Ukraine is the reason of religious discourse investigation. The aim of this research is to analyze concept "religion» in the consciousness of young people.
\end{abstract}

Materials \& Methods. Free word association test (WAT) has been used for psycholinguistic analysis. The respondents have been received a questionnaire with ten words-stimuli (related to religious discourse: clergyman, priest, theologian, church, religion, preaching, sacraments, faith, sin, prayer). In this article, we only analyzed associations for "religion». The sample consisted of 246 students (biologists, psychologists and publishers) from Lesya Ukrainka Eastern European National University.

Results. As a result of the free WAT, 258 responses to the stimulus word "religion" were, among them 106 different associations. Among the most frequent responses were "faith», "Christianity», "church» and "orthodoxy». In general, respondents often 
associate religion with the church and specific faiths (in this case, Christianity and Orthodoxy). The grammar and logical characteristics of the obtained associations have been analyzed. It has been shown that central paradigmatic reactions to the stimulus word "religion" predominate. The thematic features of the associations to "religion" have been analyzed. Ten different thematic groups have been identified: faith; types and directions of religion; outlook; church; morality; emotions; people; negative evaluations. The most numerous thematic group is "faith" which binds "religion" with faith in God and higher powers. The least numerous thematic groups are "morality», "emotions» and "people».

Conclusions. Students view religion on two sides. On the one hand, as a set of beliefs or a certain outlook. On the other hand, they restrict this concept to the community of like-minded, who meet in the church. In general, this thematic variety of the associations indicates a high level of students' awareness of the concept of "religion". Prospects for further study of this problem lie in an in-depth psycholinguistic analysis of religious discourse.

Key words: concept, free association test, religion, religious discourse, students.

\section{Вступ}

У грудні 2018 року в Україні офіційно проголошено об'єднання українських церков в єдину Православну церкву України. Така історична подія привертає увагу науковців до вивчення релігійного дискурсу.

Дослідження у сфері психології релігійного дискурсу на сучасному етапі розвитку науки перетворилося із вузької галузі, на тему широкого інтересу в загальній психології, що передбачає нейрокогнітивні, розвивально-особистісні та соціально-культурні сфери. У той же час психологія релігійного дискурсу стала все більш інтернаціоналізованою, тобто постійно доповнюється дослідженнями різних регіонів і культур (Paloutzian, 2017).

Однією 3 історичних місій релігії, що набуває в сучасному світі все більшої актуальності, $є$ формування відчуття єдності людського роду, значущості неперехідних загальнолюдських моральних норм і цінностей. Відчуття приналежності до соціальної групи формує добробут людини та їі здоров’я. Дати людині віру означає у десять разів збільшити іiі психологічну стійкість. Однак, варто згадати, що релігія може демонструвати зовсім інші настрої, зокрема фанатизм, непримиренність до людей іншої віри тощо. 
Кониепт «РЕЛІГІЯ»у свідомості молоді: психолінгвістичний...

Сучасна українська психологиня Н.M. Савелюк (2015) детально розглядає питання дискурсу загалом та релігійного зокрема, і визначає його як двостороннє явище. 3 одного боку як

«прочес когнітивно-мовленнсвої активності у релігійно релевантній сочіально-комунікативній ситуації, щзо передбачає рецепцію, передавання та/або творення (співтворення) певних релігійних текстів у певному контексті, а з іншого - як поточний результат даної активності, щуо творить відповідну дискурсивну картину (модель) світу» (Савелюк, 2017: 84).

Тобто релігійний дискурс дослідниця розглядає досить широко і як процес релігійної активності, і як іiі результат.

У межах вивчення релігійного дискурсу В.І. Постовалова пропонує окремий науковий напрямок - релігійну концептологію, що спрямована на дослідження релігійних концептів та їхньої значимості в духовному світі людини. Науковиця розглядає концепт як ментальне утворення свідомості та духовну (онтологічну) реальність (Постовалова, 2012).

Закордонні сучасні науковці трактують концепт як форму ментальної репрезентації когнітивного набору об'єктів, незалежно вони природні, штучні чи гіпотетичні. Це своєрідні набори ознак, пов'язаних за значенням чи функцією. Грунтуючись на типах категоризації, науковці виокремлюють дві основні групи концептів: класичні та природні (Eysenck, 2012). Класичні концепти базуються на емпіричному підході, який передбачає, що можливо однозначно визначити приналежність поняття до категорії з суворими межами та бінарними ознаками. Класичні концепти вважаються чітко визначеними, 3 конкретними межами та структурою. На противагу класичним концептам, існують природні, які менш точні і походять від реалізму, спричинені досвідом та впливом ситуації. Такі концепти $\epsilon$ нечіткими, елементами повсякденних уявлень про світ. До цієї групи належать емоційні концепти, які активно досліджуються закордонними вченими (Gawda, 2019). Так, природними концептами ми можемо назвати любов, віру, душу. Тоді як релігія виступає як класичний концепт межі якого чітко окреслені людиною.

Концепт «релігія» $є$ одним із самих складних у межах релігійного дискурсу через свою неоднозначність і теологічну орієнтацію. Науковці-постмодерністи стверджують, що визначення релігії неможливе. А ті функціональні визначення які на 
Concept "Religion» in the Consciousness of Young People...

сьогоднішній день існують, як правило, $€$ твердженнями про наслідки релігії (Bruce, 2011; Pamela \& Strathern, 2014).

У етіології релігія трактується як спосіб встановлення зв'язку між служінням Богові, осередком богословських чеснот і православ'ям (Vorontsov, 2016). Релігія - це складне соціальне й духовне явище; сукупність вірувань та духовних практик (як індивідуальних так і колективних), які відображають й регулюють зв>язок людини 3 трансцендентною дійсністю (Крупська, 2009: 5).

Релігія - концепт інтелектуальний, пов'язаний 3 абстрактним мисленням. На відміну від інших концептів, пов'язаних із віруванням та поклонінням сакральному, концепт релігія $є$ відносно новим. Це підтверджується відсутністю цього концепту у ідіомах, прислів'ях і приказках. Термін релігія спочатку використовували римляни (ще у дохристовий період) для позначення поклоніння демонам. Для позначення системи вірувань він використовувався спершу у християнстві та поступово розширився до позначення всіх форм соціальної демонстрації, пов’язаної з чимось священним. Релігію розглядають як потребу людини у спілкуванні із Богом, а також систему вірувань, догм та практик, які визначають відношення між людиною та божеством (Петрик, 2016). Релігія

«в своїй доктрині, етиц̧і $i$ ритуалі розкриває перед людиною широкий горизонт понять, пояснюе їй сенс життя, гарантує вищі цінності $i$ норми, робить людину членом духовного суспільства, наділяє ї̈ духовного родиною, надає обтрунтування для протесту і спротиву всьому неправедному» (Докаш, 2015).

У різних країнах особливе трактування релігії. Так, у Китаї «релігію» розуміють як один із способів, якими звичайні люди гармонізують свої суперечливі ритуальні практики та ідеї про світ. Всі інші трактування релігії вважаються більш вузькими і такими, що сприяють збільшенню сфер «культури» i «забобон» (Colijn, 2018). Португальські теологи здійснюють дослідження політизованої релігії або ж теологізованих політичних концепцій. На їхню думку релігія - це історичний, політичний, соціологічний та культурний продукт (Schmid, 2018). Дослідники з Великобританії досліджують поняття релігії через ритуал та ритуальну поведінку (Stewart \& Strathern, 2014). Великий тлумачний словник сучасної української мови (Бусел, 2005) пропонує декілька визначень поняття «релігія»: 1) погляди та уявлення, в основі яких лежить віра в існування 
надприродних сил - богів, духів, душ, в їхнє панування над світом. Та чи інша віра, віросповідання; 2) те, що сліпо наслідують, чому поклоняються.

Дослідник із Великобританії Ф. Уоттс (Watts, 2017) у своїй книзі «Психологія, релігія і духовність» має на меті зробити психологію корисною для християн, особливо тих, хто займається пастирським служінням. Автор виокремлює фундаментальні аспекти релігії, такі як досвід, практика і віра та стверджує про неможливість розгляду окремо одного аспекту, лише у комплексі з іншими.

Інші дослідники описують три основні сфери застосування концепту релігії: релігія як віра або сенс, релігія як ідентичність, релігія як структуровані суспільні відносини. Деякі застосування, які колись були важливими, є в даний час рецесивними, включаючи марксистські підходи до релігії як ідеології, і парсонські концепції релігії як норми і цінності. Виникають також нові застосування, включаючи «матеріальну» релігію, а також розуміння релігії як дискурсу і релігії як практики (Woodhead, 2011).

Автор книги «Концепт релігія: визначення та вимірювання сучасних переконань і практик» Ганс Шильдерман вважає, що розуміння поняття релігії кардинально відрізняється у науці, церковному вченні і практиці вірувань. Вивчення концепту релігія дослідник здійснює емпірично, вивчаючи його у взаємозв'язку 3 тривалістю життя, соціалізацією у школі, професійною діяльністю у церквах та лікарнях (Schilderman, 2014).

Незважаючи на велику кількість спроб визначення поняття релігії, проблема панівних уявлень у свідомості української молоді щодо концепту «релігія» $є$ майже не дослідженою. Саме тому, метою нашої наукової розвідки $є$ психолінгвістичний аналіз вербальних репрезентацій концепту «релігія». Таким чином, новизна нашого дослідження полягає у встановленні домінуючих уявлень молоді та компонентів семантичного простору концепту «релігія».

\section{Методи та методики дослідження}

Для реалізації мети нашого дослідження було використано вільний асоціативний експеримент, як «інструмент вимірювання несвідомих компонентів семантичного простору реципієнтів» 
(Засєкіна \& Засєкін, 2008: 55). Асоціативний експеримент дає можливість наблизитися до вербальної пам>яті, ментального лексикону, культурних стереотипів і виявити зміст концепту в когнітивній свідомості носіїв мови. Методика проведення вільного асоціативного експерименту полягає у пред'явленні списку стимульних слів для респондентів, які мають завдання - відповідати першим словом, яке приходить на думку. Асоціативна реакція має реалізовуватися швидко, без роздумів. У вільному асоціативному експерименті ми не ставили досліджуваним ніякі обмеження на словесні реакції. Асоціативний експеримент, як метод дослідження семантичного простору студентства також застосовує такий вчений як Dina Abdel Salam El-Dakhs (El-Dakhs, 2017).

Вибірку склали 246 студентів віком 17-20 років із Східноєвропейського національного університету імені Лесі Українки, серед яких 102 - студенти-біологи; 96 - студентипсихологи; 48 - студенти-видавці. Досліджувані отримали анкету 3 десятьма словами-стимулами, що пов'язані 3 релігійним дискурсом (священнослужитель, священик, богослов, церква, релігія, проповідь, таїнства, віра, гріх, молитва). У цій статті ми аналізуємо виключно асоціації на «релігія». Психолінгвістичний аналіз концептів «проповідь» та «церква» представлений у наших попередніх публікаціях (Коструба, 2018; Чміль, 2017). Результати аналізу реакцій на інші стимули буде висвітлено у наших подальших наукових працях. На заповнення анкети студентам надавалось не більше 5 хвилин. Відмов не було. Проведення експерименту дало можливість отримати всього 258 реакцій на слово-стимул «релігія», серед яких 106 різних асоціацій. Кількість отриманих асоціацій перевищує кількість досліджуваних, оскільки вільний асоціативний експеримент дає можливість надати декілька словесних реакцій.

\section{Результати та дискусії}

Здійснений аналіз отриманих асоціацій дозволив виявити найчастотніші реакції на слово-стимул «релігія», серед яких «віра», «християнство», «церква» та «православ'я». Тобто загалом опитувані часто пов'язують релігію із церквою та конкретними віруваннями (у даному випадку це християнство і православ’я). 
Кониепт «РЕЛІГІЯ»у свідомості молоді: психолінгвістичний...

Отримані асоціації на «релігія» оцінювалися за логічним критерієм. А саме кожне 3 отриманих слів ми розподіляли до певного типу реакцій - центральної чи периферійної. Периферійні логічні асоціації представлені меншістю реакцій (усього 41). Це такі асоціації: «суб'єктивна думка», «плач», «тепло», «масове скупчення людей», «спокій», «гроші,», «маячня», «бізнес», «війна», «уява», «Що? Де? Коли?» та ін. Так, лише 15,9\% від усіх отриманих асоціацій є периферійними логічними реакціями, які окреслюють індивідуальний досвід респондентів, $\epsilon$ нетиповими. Решта 84,1\% отриманих асоціацій $є$ центральними логічними реакціями та виражають прямий зв'язок слова-стимула та асоціацій («Бог», «вірування», «світогляд», «церква», «християнство» тощо). Переважання центральних реакцій на слово «релігія» свідчить про обізнаність студентів із цим поняттям, високий рівень володіння мовою та послідовне логічне мислення.

Асоціації на концепт «релігія» також було проаналізовано за граматичним критерієм. Ми розглядали до якого типу реакцій можна віднести кожне 3 отриманих слів - парадигматичної чи синтагматичної. Виявлено, що 38 слів-асоціацій є синтагматичними реакціями, серед яких «нав'язане», «різні кольори», «духовний носій,», «різне тлумачення», «віра в завтрашній день», «вибір Бога, в якого віруєш і законів яких дотримуєшся», «затята віра в щось», «для всіх» тощо. Синтагматичні асоціації становлять 14,7\%. Парадигматичних реакцій (відповідей тієї самої частини мови, що й слово-стимул «релігія») серед отриманих асоціацій виявилася більшість. У відсотковому співвідношенні парадигматичні реакції складають 85,3\%. Переважання парадигматичних граматичних асоціацій свідчить про комплексне та аналітичне мислення студентів.

Оцінка отриманих асоціацій на «релігія» здійснена також згідно з тематичним критерієм. Опрацювання масиву асоціацій дало можливість виокремити вісім тематичних категорій: віра; види та напрямки релігії; світогляд; церква; мораль; емоції; люди; негативні оцінки (Табл. 1).

Найчисельнішою виявилась тематична категорія, яка пов'язує «релігію» 3 вірою (34,5\%), у межах якої досліджувані надавали такі асоціації як «віра», «Бог», «віра в Бога», «віросповідання» та «вірування». Студенти вважають, що в основі релігії $є$ віра у Бога, «у вищі сили», «в щось», «в завтрашній день». Тобто релігія 
Concept "Religion» in the Consciousness of Young People...

передбачає прийняття певних речей чи думок як істини лише на основі суб’єктивних, внутрішніх переконань. Основою релігії студенти вважають віру. У цій тематичній категорії виявлено таку реакцію на стимул «релігія» як «вірність», яка передбачає відданість та моральну чесноту. Ця реакція за своїм змістом може бути віднесена у іншу теоретичну категорію - мораль. Але ми розглядаємо вірність як похідне від слова віра. Тому «вірність» як асоціацію на «релігію» включаємо у категорію віра (Рис. 1).

Таблиця 1. Тематичні групи асоціацій концепту «релігія» (258 реакцій)

\begin{tabular}{|c|c|c|}
\hline № & $\begin{array}{l}\text { Тематична } \\
\text { категорія }\end{array}$ & Асоціації, N \\
\hline 1 & Bipa & $\begin{array}{l}\text { Вiра (52), Бог (7), Віра в Бога (7), Віросповідання (5), Вірування (5), } \\
\text { Віра у вищі сили (3), Віра в щось (2), Напрям віри, якій включає } \\
\text { філософські роздуми, Течія віри, Вірування людини в щось, Віра } \\
\text { в завтрашній день, Сповідування, Затята віра в щось, Віра в Бога, } \\
\text { прийняття його законів, Віра в певного Бога (богів), Вірність }\end{array}$ \\
\hline 2 & $\begin{array}{l}\text { Види та } \\
\text { напрямки } \\
\text { релігії }\end{array}$ & $\begin{array}{l}\text { Християнство (37), Православ'я (8), Християнська (7), Православна (3), } \\
\text { Католицизм (3), Християнин (3), Православність, Православне } \\
\text { християнство, Ватикан, Ісус, Християни, Католики, Мусульманство }\end{array}$ \\
\hline 3 & Світогляд & $\begin{array}{l}\text { Світогляд (4), Вибір (3), Світобачення (2), Напрямок (2), Культура (2), } \\
\text { Поклоніння (2), Спасіння (2), Повинна бути одна, Приналежність, Світ, } \\
\text { Релігійність, Філософія, Наука, Пошук відповідей на свої питання про } \\
\text { сенс буття, Переконання людини, Переконання особистості, Думки, } \\
\text { Масовість, Безмежність, Уява, Суб'єктивна думка, Ідея, Вибір Бога, в } \\
\text { якого віруєш і законів яких дотримуєшся, В кожного своя, Для всіх, } \\
\text { Духовне прагнення людини, Духовний носій, Різне тлумачення }\end{array}$ \\
\hline 4 & Церква & $\begin{array}{l}\text { Церква (9), Книга (4), Біблія (3), Молитва (2), Молитовник, } \\
\text { Священнослужитель, Священик, Святотаїнство, Святиня, Кадило }\end{array}$ \\
\hline 5 & $\begin{array}{l}\text { Негативні } \\
\text { оцінки }\end{array}$ & $\begin{array}{l}\text { Незнання, Собака, Гроші, Маячня, Секта, Система бізнесу, яка не несе } \\
\text { нічого корисного, Бізнес, Війна, Нав'язане, Пафос, Річ, яка віддаляє } \\
\text { від Бога, Дим, Різні кольори, Маразм, Що? Де? Коли? }\end{array}$ \\
\hline 6 & Мораль & $\begin{array}{l}\text { Настанови, Закон, Рамки, Духовність, Цінності, Заповіді, Заповіт, } \\
\text { Відданість }\end{array}$ \\
\hline 7 & Емоції & Спокій (2), Плач, Тепло, Радість, Любов, Надія, Рівновага \\
\hline 8 & Люди & $\begin{array}{l}\text { Народ, Однодумці, Збори, Віруючі, Масове скупчення людей, Спосіб } \\
\text { організувати людей в стадо, Ми+, Люди }\end{array}$ \\
\hline
\end{tabular}

Наступна за чисельністю тематична група «види та напрямки релігії» (26,4\%). До цієї тематичної категорії потрапили такі асоціації як «Християнство», «Православ'я», «Католицизм» тощо. Так, молодь найчастіше говорячи про релігію має на увазі їі конкретний напрямок або ж відразу характеризує іiі як «християнську» чи 
«православну». Найчастотніші асоціації із цієї групи відображають притаманні регіону опитування напрямки християнства: православ'я і католицизм. Також у межах цієї категорії згадувалося мусульманство, що є не типовим для українських студентів. Також серед асоціацій цієї категорії виявлено реакцію «Ватикан», ймовірно опитувані вважають його центром релігійного життя.

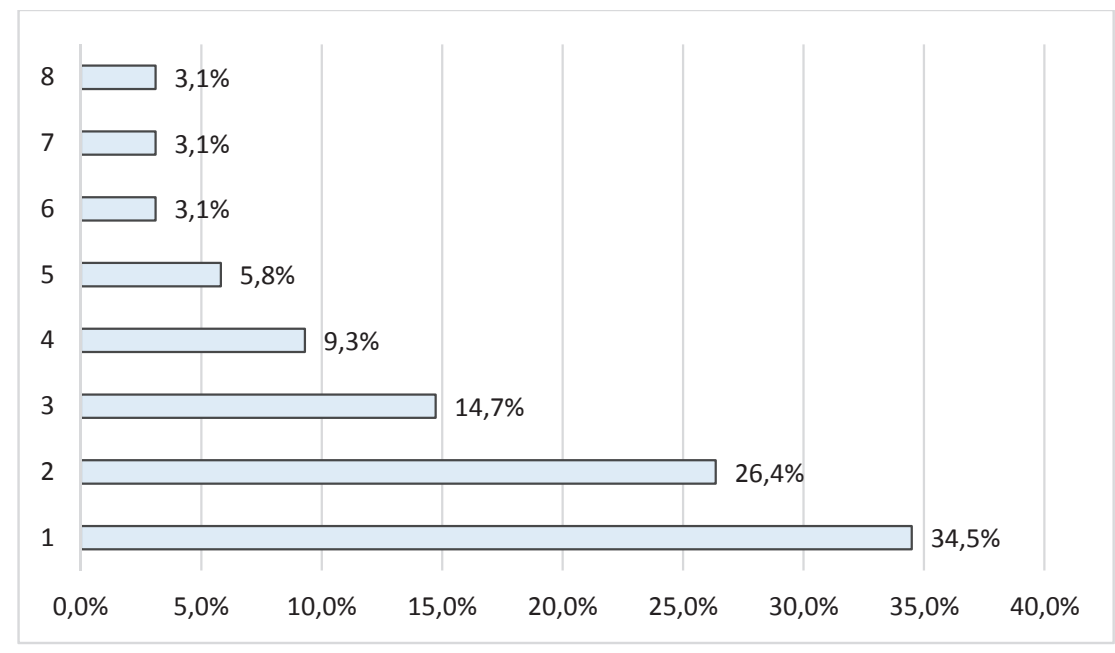

Рис. 1. Тематична структура асоиіацій на «релігія»

Примітка: 1 - Віра; 2 - Види та напрямки релігії; 3 - Світогляд; 4 - Церква; 5 - Негативні оцінки; 6 - Мораль; 7 - Емоції; 8 - Люди.

Достатньо часто серед асоціацій траплялися реакції, що пов'язують релігію із особливим світоглядом $(14,7 \%)$, а саме це реакції «світогляд», «вибір», «світобачення», «напрямок», «культура» та ін. Ця категорія є найбільш різносторонньою, оскільки світогляд слід розглядати не лише як набір «переконань», «думок» та «ідей», але і як програми поведінки та діяльності. Поведінкові аспекти релігійного світогляду відображені у таких асоціаціях студентів як «поклоніння», «спасіння», «пошук відповідей на свої питання про сенс буття», «вибір Бога, в якого віруєш і законів яких дотримуєшся». Тобто опитувані розглядають релігію не як пережиток минулого, а як частину чи основу світогляду, яка впливає на поведінку і діяльність. В межах цієї категорії студенти демонструють погляд на релігію як «науку» та «філософію», яка існує «для всіх», але разом з цим вона «у кожного своя». Опитувані 
підкреслюють «масовість» i «безмежність» релігії, яка реалізує «духовні прагнення людини».

Тематична категорія «церква» тісно пов'язує «релігію» is конкретними речами та ритуалами, що відображається у таких асоціаціях: «церква», «книга», «Біблія», «молитва» та ін. Частота вживання реакцій цієї тематичної категорії становить 9,3\%. Група «церква» відображає практичну частину реалізації релігійного життя людини через діяльність священнослужителів, молитву, Біблію тощо. Крім того, серед асоціацій цієї категорії зустрічається реакція «святотаїнство», що відображає свято долучення до духовного i обрядового життя церкви. Допомагає звершувати таїнства «священик» чи «священнослужитель», діяльність якого є важливим елементом релігії.

Особлива серед виокремлених тематичних категорій є група «негативні оцінки», що становить 5,8\% від усіх реакцій. У межах цієї групи релігія описується як незрозуміле («дим», «маразм», «Що? Де? Коли?», «незнання», «маячня») i не природнє («секта», «пафос», «нав’язане», «річ, яка віддаляє від Бога») явище, яке несе розбрат («війна», «різні кольори») і метою своєю має збагачення («гроші», «система бізнесу, яка не несе нічого корисного», «бізнес»). Тобто, деякі студенти бачать у релігії не об'єднуючий, підтримуючий простір для реалізації духовних прагнень людини, а підстава для поділу на «різні кольори». Також у межах цієї категорії спостерігається засудження опитуваними надмірний фанатизм до релігії та іiі елементів. Так, номінальна релігійна прихильність і відвідування церкви напоказ трактується студентами як «пафос».

«Мораль» як тематична категорія представлена реакціями «настанови», «закон», «рамки», «цінності», «духовність», «заповіді», «заповіт», «відданість», що становлять всього 3,1\% усіх асоціацій. Тобто релігія для студентів іноді служить як зразок моральних законів і обмежень, але разом із тим є носієм цінностей та духовності. Опитувані характеризують релігію через призму відданості їі заповідям і цінностям.

Аналогічна за чисельністю виявилась тематична група «люди», що відображає розуміння релігії як певного зібрання. До цієї категорії належать асоціації «однодумці», «збори», «віруючі», «народ», «масове скупчення людей», «ми+», «люди». Тобто, студенти розглядають релігію через призму зібрання однодумців. 
Кониепт «РЕЛІГІЯ»у свідомості молоді: психолінгвістичний...

Так, існування релігії опитувані розглядають невіддільно від людей як носіїв цієї релігійності. До цієї тематичної групи потрапила асоціація «спосіб організувати людей в стадо», яка може також бути віднесена до групи «негативні оцінки». Ми іiі віднесли до тематичної групи «люди», оскільки у цьому словосполученні ключовим $є$ поняття люди.

Як і дві попередні тематичні групи, категорія «емоції» $\epsilon$ нечисельною і становить всього 3,1\% усіх асоціацій. Реакції, що вміщує ця група це «спокій», «плач», «тепло», «радість», «любов», «надія», «рівновага». Загалом усі зазначені асоціації пов’язують релігію з позитивними емоційними станами і відображають хороше ставлення студентів до релігії. Релігія може позитивно впливати на психологічний та емоційний стан (Watts, 2017). У релігійних обрядах майже неодмінно присутні музика, співи, тривале ритмічне повторення одноманітних слів і рухів, що викликають певні емоції. Загалом, релігія при усій своїй внутрішній глибині зберігає достатню «зовнішню простоту і своєрідну цілісність і впорядкованість», а як досліджено психологами -

«будь-яка структурна організація, яка спрощує сприймання зовнішнього світу, породжує позитивні емоційні переживання» (Матласевич, 2013).

Більшість релігійних таїнств спрямовані на те, «щоб у людини відбулася зміна мислення» (Матласевич, 2013: 97). У процесі релігійної сповіді відбувається «зняття» негативних переживань, накопичених в людини, своєрідний катарсис.

\section{Висновки}

Психолінгвістичний аналіз концепту «релігія» методом вільного асоціативного експерименту дозволив виявити, що молодь описує цей концепт через такі поняття як віра, церква, християнство та православ'я. Тобто, найчастіше концепт релігія досліджувані визначають як певні вірування (для опитаних найтиповішими $\epsilon$ християнство і православ'я) та пов'язують цей концепт 3 місцем, де найчастіше звертаються до релігії (церква). У отриманому асоціативному матеріалі переважають центральні логічні та 
парадигматичні граматичні реакції, що демонструє обізнаність студентів щодо досліджуваного концепту.

Тематичний аналіз отриманих асоціацій дав можливість виявити домінування реакцій, що пов'язані з вірою. Тобто релігія асоціюється із некритичним прийняттям усіх істин та догматів, які вона сповідує. Крім того, асоціації досліджуваних стосувалися видів та напрямків релігії, світогляду, церкви, моралі, емоцій, людей та негативних оцінок. Опитувані розглядають релігію не лише як філософію чи науку, а як частину чи основу світогляду, яка впливає на повсякденне життя, на емоції та цінності. Найменші за чисельністю серед отриманих асоціацій виявилися тематичні групи «мораль», «емоції» та «люди». Студенти розглядають релігію не лише як сукупність вірувань чи певний світогляд, але й звужують це поняття до спільноти однодумців, що зустрічаються у церкві. Загалом, студенти продемонстрували усвідомлення змісту концерту релігія, незважаючи на наявність тематичної групи негативні оцінки, яка відображає індивідуальний досвід окремих опитаних.

Перспективи дослідження вбачаємо в подальшому психолінгвістичному аналізі релігійного дискурсу та концептів «релігія», «віра», «таїнства», «богослов». Особливо цінним вважаємо дослідження уявлень молоді щодо релігійних концептів, оскільки вони є носіями нового бачення на традиційні поняття.

\section{Література}

Бусел, В.Т. (Ред.). (2005). Великий тлумачний словник сучасної украӥнської мови. Київ: Перун.

Докаш, В. (2015). Релігійність українського суспільства: суспільні виміри і фактори змін. Релігія та Соціум, 3 (19), 113-120.

Засєкіна, Л.В., \& Засєкін, С.В. (2008). Психолінгвістична діагностика. Луцьк: Вежа. Коструба, Н.С. (2018). Вербальна репрезентація концепту «церква» (за даними асоціативного експерименту). Psycholinguistics, 23 (1), 160-174. https://doi. org $/ 10.5281 /$ zenodo. 1211185

Крупська, О.І. (2009). Ставлення до батьків як чинник розвитку релігійних уявлень осіб юнацького віку. Автореф. дис. канд. психол. наук. Київ.

Матласевич, О.В. (2013). Християнські цінності як основа психологічної практики. Наукові записки Національного університету «Острозька академія». Сер.: Психологія і педагогіка, 25, 96-100.

Петрик, Т. (2016). Фреймова модель концепту «релігія» в езотеричному дискурсі. Вісник Львівського університету. Серія іноземні мови, 23, 10-17.

Постовалова, В.И. (2012). Религиозные концепты в теолингвистическом представлении. А.К. Гадомской \& К. Кончаревич (Ред.), Теолингвистика 
Концеепт «РЕЛІГІЯ»у свідомості молоді: психолінгвістичний...

(с. 143-152). Београд: Универзитет у Београду. Православни богословски факултет.

Савелюк, Н.М. (2015). Дискурс як міждисциплінарне поняття та його психологічні виміри. Психологічні перспективи, 26, 251-264.

Савелюк, Н.М. (2017). Психологія розуміння релігійного дискурсу. Київ: КНТ.

Чміль, Н.С. (2017). Вербальна репрезентація концепту «проповідь» (за даними асоціативного експерименту). East European Journal of Psycholinguistics, 4 (1), 30-39. https://doi.org/10.5281/zenodo.824410

El-Dakhs, D.A.S. (2017). The Effect of Language Exposure and Word Characteristics on the Arab EFL Learners' Word Associations. Journal of Psycholinguistic Research, 46 (4), 1033-1052. https://doi.org/10.1007/s10936-017-9477-z

Bruce, S. (2011). Defining religion: a practical response. International Review of Sociology, 21 (1), 107-120. https://doi.org/10.1080/03906701.2011.544190

Colijn, B. (2018). The Concept of Religion in Modern China: A Grassroots Perspective. Exchange-journal of Missiological and Ecumenical Research, 47 (1), 53-70. https://doi.org/10.1163/1572543X-12341467

Eysenck, M.W. (2012). Fundamentals of cognition (2 ${ }^{\text {nd }}$ ed.). Milton Park: Psychology Taylor \& Francis.

Gawda, B. (2019). The Structure of the concepts related to love spectrum: emotional verbal fluency technique application, initial psychometrics, and its validation. Journal of Psycholinguistic Research, 48, 1339-1361. https://doi.org/10.1007/ s10936-019-09661-y

Paloutzian, R.F. (2017). Psychology of Religion in Global Perspective: Logic, Approach, Concepts. International Journal for the Psychology of Religion, 27 (1), 1-13. https://doi.org/10.1080/10508619.2017.1241529

Pamela, J.S., \& Strathern, A. (2014). Ritual: Key Concepts in Religion. London: Bloomsbury.

Schilderman, H. (2014). The Concept of Religion: Defining and Measuring Contemporary Beliefs and Practices. Leiden: Brill.

Schmid, K (2018). Os primórdios da religião politizada: a teologização de conceitos políticos imperiais no Israel Antigo. Estudos Teologicos, 58 (2), 483-496. https:// doi.org/10.22351/et.v58i2.3499

Stewart, P.J., \& Strathern, A. (2014). Ritual: Key Concepts in Religion. London: Bloomsbury Academic.

Vorontsov, S. (2016). Some considerations on the concept of religion in the etymologiae of isidore of seville. Athenaeum-studi Periodici di Letteratura $e$ Storia Dell Antichita, 104 (1), 245-250.

Watts, F. (2017). Psychology, Religion, and Spirituality: Concepts and Applications. Cambridge: University of Cambridge Press.

Woodhead, L. (2011). Five concepts of religion. International Review of Sociology, 21 (1), 121-143. https://doi.org/10.1080/03906701.2011.544192

\section{References}

Busel, V.T. (Ed.). (2005). Velykyi tlumachnyi slovnyk suchasnoi ukrainskoi movy [Great Dictionary of the modern Ukrainian language]. Kyiv: Perun [in Ukrainian]. 
Dokash, V. (2015). Relihiinist ukrainskoho suspilstva: suspilni vymiry i faktory zmin [Religiosity of Ukrainian society: social dimensions and factors of change]. Relihiia ta Sotsium - Religion and Socium, 3 (19), 113-120 [in Ukrainian].

Zasiekina, L.V., \& Zasiekin, S.V. (2008). Psykholinhvistychna Diahnostyka [Psycholinguistic Diagnostics]. Lutsk: Vezha [in Ukrainian].

Kostruba, N. (2018). Verbalna reprezentatsiya kontseptu «tserkva» (za danymyasotsiatyvnoho eksperymentu) [Verbal representation of the concept «church» (according to the associative experiment)]. Psiholingvistika Psycholinguistics, 23 (1), 160-174. https://doi.org/10.5281/zenodo.1211185 [in Ukrainian].

Krupska, O.I. (2009). Stavlennia do batkiv yak chynnyk rozvytku relihiinykh uiavlen osib yunatskoho viku [Attitude towards parents as a factor in the development of persons' religious beliefs in adolescence]. Extended abstract of Candidate's thesis. Kyiv [in Ukrainian].

Matlasevych, O.V. (2013). Khrystyianski tsinnosti yak osnova psykholohichnoi praktyky [Christian values as the basis of psychological practice]. Naukovi zapysky Natsionalnoho universytetu «Ostrozka akademiia». Ser.: Psykholohiia $i$ pedahohika - Scientific notes of the Ostroh Academy National University. Ser: Psychology and Pedagogy, 25, 96-100 [in Ukrainian].

Petryk, T. (2016). Freimova model kontseptu «relihiia» v ezoterychnomu dyskursi [Frame model of the concept «religion» in esoteric discourse]. Visnyk Lvivskoho universytetu. Seriia inozemni movy - Visnyk of the Lviv University. Series Foreign Languages, 23, 10-17 [in Ukrainian].

Postovalova, V.I. (2012). Religioznyie kontsepti v teolingvisticheskom predstavlenii [Religious concepts in teolinguistic representation]. In A.K. Gadomskoj \& K. Koncharevich (Eds.), Teolingvistika - Teolinguistiks (pp. 143-152). Beograd: Belgrade University [in Russian].

Saveliuk, N. (2015). Discourse as an Interdisciplinary Concept and its Psychological Dimensions [Dyskurs yak mizhdystsyplinarne poniattia ta yoho psykholohichni vymiry]. Psychological Prospects Journal, 26, 251-264 [in Ukrainian].

Saveliuk, N.S. (2017). Psykholohiia rozuminnia relihiinoho dyskursu [Psychology of Understanding Religious Discourse]. Kyiv: KNT [in Ukrainian].

Chmil, N. (2017). Verbalna reprezentatsiya kontseptu «propovid» (za danymy asotsiatyvnoho eksperymentu) [Verbal Representation of the Concept «Sermon» (Based on the Association Test)]. East European Journal of Psycholinguistics, 4 (1), 30-39. https://doi.org/10.5281/zenodo.824410 [in Ukrainian].

El-Dakhs, D.A.S. (2017). The Effect of Language Exposure and Word Characteristics on the Arab EFL Learners' Word Associations. Journal of Psycholinguistic Research, 46 (4), 1033-1052. https://doi.org/10.1007/s10936-017-9477-z

Bruce, S. (2011). Defining religion: a practical response. International Review of Sociology, 21 (1), 107-120. https://doi.org/10.1080/03906701.2011.544190

Colijn, B. (2018). The Concept of Religion in Modern China: A Grassroots Perspective. Exchange-journal of Missiological and Ecumenical Research, 47 (1), 53-70. https://doi.org/10.1163/1572543X-12341467

Eysenck, M.W. (2012). Fundamentals of cognition (2 ${ }^{\text {nd }}$ ed.). Milton Park: Psychology Taylor \& Francis.

Gawda, B. (2019). The Structure of the concepts related to love spectrum: emotional verbal fluency technique application, initial psychometrics, and its validation. 
Концеепт «РЕЛІГІЯ»у свідомості молоді: психолінгвістичний...

Journal of Psycholinguistic Research, 48, 1339-1361. https://doi.org/10.1007/ s10936-019-09661-y

Paloutzian, R.F. (2017). Psychology of Religion in Global Perspective: Logic, Approach, Concepts. International Journal for the Psychology of Religion, 27 (1), 1-13. https://doi.org/10.1080/10508619.2017.1241529

Pamela, J.S., \& Strathern, A. (2014). Ritual: Key Concepts in Religion. London: Bloomsbury.

Schilderman, H. (2014). The Concept of Religion: Defining and Measuring Contemporary Beliefs and Practices. Leiden: Brill.

Schmid, K (2018). Os primórdios da religião politizada: a teologização de conceitos políticos imperiais no Israel Antigo. Estudos Teologicos, 58 (2), 483-496. https://doi.org/10.22351/et.v58i2.3499

Stewart, P.J., \& Strathern, A. (2014). Ritual: Key Concepts in Religion. London: Bloomsbury Academic.

Vorontsov, S. (2016). Some considerations on the concept of religion in the etymologiae of isidore of seville. Athenaeum-studi Periodici di Letteratura e Storia Dell Antichita, 104 (1), 245-250.

Watts, F. (2017). Psychology, Religion, and Spirituality: Concepts and Applications. Cambridge: University of Cambridge Press.

Woodhead, L. (2011). Five concepts of religion. International Review of Sociology, 21 (1), 121-143. https://doi.org/10.1080/03906701.2011.544192

\section{АНОТАЦІЯ}

Мета дослідження. Статтю присвячено психолінгвістичному аналізу концепту "релігія», що існує в свідомості молоді.

Процедура дослідження. Дослідження реалізувалося шляхом вільного асоціативного експерименту. Досліджувані отримали анкету з десятьма словами-стимулами, що пов'язані з релігійним дискурсом. У цій статmі ми аналізуємо виключно асоціації на "релігія». Вибірку склали 246 студентів віком 17-20 років із Східноєвропейського національного університету імені Лесі Українки, серед яких студенти-біологи, психологи та видавці.

Результати. У результаті здійсненого асоціативного експерименту концепту "релігія» було отримано всього 258 реакцій, серед яких 106 різних асоціацій. Аналіз асоціацій дозволив виявити найчастотніші реакції, серед яких "віра", "християнство», «церква» та «православ'я». Тобто загалом опитувані часто пов'язують релігію із церквою та конкретними віруваннями (у даному випадку це християнство і православ'я). Опрацювання отриманих асоціацій на "релігія» здійснено за логічним критерієм, що дозволило виявити переважання центральних реакцій на слово-стимул. За граматичним критерієм серед отриманих асочіацій на "релігія» переважають парадигматичні реакції. Аналіз отриманих асоціацій на "релігія» здійснено за тематичним критерієм, що дало змогу виокремити вісім різних тематичних категорій: віра; види та напрямки релігії; світогляд; церква; мораль; емоції; люди; негативні оцінки. Найчисельнішою виявлено тематичну групу, яка пов'язує «релігію» з вірою 
Concept «Religion» in the Consciousness of Young People...

у Бога та вищі сили. Найменш чисельнішими серед отриманих асоціацій виявились тематичні групи «мораль», "емоції» та "люди».

Висновки. Студенти розглядають релігію не лише як сукупність вірувань чи певний світогляд, але й звужують це поняття до спільноти однодумців, що зустрічаються у церкві. Загалом, студенти продемонстрували усвідомлення та розуміння змісту концерту релігія, незважаючи на наявність тематичної групи "негативні оцінки», яка відображає індивідуальний досвід окремих опитаних. Перспективи дослідження вбачаємо в подальшому психолінгвістичному аналізі релігійного дискурсу.

Ключові слова: концепт, вільний асоціативний експеримент, релігія, релігійний дискурс, студенти.

\section{Коструба Наталия. Концепт "Религия» в сознании молодежи: психолингвистический анализ}

\section{АННОТАЦИЯ}

Цель исследования. Статья посвящена психолингвистическому анализу концепта "религия», который функционирует в сознании молодежи.

Прочедура исследования. Исследование проводилось путем свободного ассоциативного эксперимента. Респонденты получили анкету с десятью словами-стимулами, связанные с религиозным дискурсом. В этой статье мы анализируем исключительно ассоциации на концепт "религия». Выборку составили 246 студентов в возрасте 17-20 лет из Восточноевропейского национального университета имени Леси Украинки, среди которых студентыбиологи, психологи и издатели.

Результаты. В результате проведенного ассоциативного эксперимента концепта "религия» было получено 258 реакций, среди которых 106 различных ассочиаций. Анализ ассоциаций позволил выявить часто употребляемые реакции, среди которых "вера», "христианство», «церковь» и "православие». В целом респонденты часто связывают религию с церковью и конкретными верованиями (в данном случае это христианство и православие). Обработка полученных ассоциаций на концепт "религия» осуществлена за логическим критерием, что позволило выявить преобладание центральных реакций на слово-стимул. По грамматическому критерию среди полученных ассоциаций на концепт "религия» преобладают парадигматические реакции. Анализ полученных ассоциаций на концепт «религия» осуществлён по тематическому критерию, что позволило выделить восемь различных тематических категорий: вера; виды и направления религии; мировоззрение; церковь; мораль; эмоции; люди; негативные оценки. Самой многочисленной обнаружена тематическая группа, которая связывает концепт "религия» с верой в Бога и высшие силы. Наименее многочисленными среди полученных ассоциаций оказались тематические группы концептов "мораль», «эмоции» u «люди». 
Кониепт «РЕЛІГІЯ»у свідомості молоді: психолінгвістичний...

Выводы. Студенты рассматривают религию не только как совокупность верований или определенное мировоззрение, но и сужают это понятие $к$ сообществу единомышленников, которые встречаются в черкви. В общем, студенты продемонстрировали осознание содержания концепта "религия», несмотря на наличие тематической группы "негативные оценки», которая отражает индивидуальный опыт отдельных опрошенных. Перспективы исследования видим в дальнейшем психолингвистическом анализе религиозного дискурса.

Ключевые слова: концепт, свободный ассоциативный эксперимент, религия, религиозный дискурс, студенты. 